\title{
Income and Expenses Of Eighth District Member Banks-1971
}

\author{
by LINDA FAULKNER CONDIT
}

$\mathbf{N}_{\mathrm{ET}}$

INCOME of member banks in the Eighth Federal Reserve District increased 7 percent in 1971 to $\$ 151$ million, compared with a 15 percent increase in 1970. Chief factors accounting for the slower income growth in 1971 were a decline in the average rate charged on loans and the increased costs of time and savings deposits. Trends in the sources and disposition of income of all member banks in the nation were generally similar to those in the Eighth District, with net income increasing 8 percent to $\$ 4.1$ billion in 1971 following an 11 percent rise in 1970 .

Operating income of District member banks increased 8 percent to $\$ 944$ million in 1971 , while operating expenses rose 11 percent to $\$ 748$ million. Since expenses rose by a larger dollar amount than earnings, income before taxes and securities gains or losses declined 4 percent, compared with a 12 percent gain in 1970. Income taxes applicable to operating income declined $\$ 13.5$ million, and net gains on security transactions after taxes rose $\$ 5.8$ million, resulting in a net income gain of $\$ 9.8$ million from the previous year.

\section{Operating Income}

Operating income of commercial banks is primarily determined by the volume and composition of earning assets held and their respective rates of return. Revenue from loans and securities is the major source of income; other sources include trust department income, service charges on deposit accounts, and other fees. The dollar volume of earning assets increased more rapidly in 1971 than in 1970 , but the rate of re turn on loans, which comprised over half of the asset portfolio, was less. Thus, operating income rose only 8 percent, compared to a 13 percent rise in the previous year.

More expansive monetary actions during the first half of 1971 as well as aggressive competition for

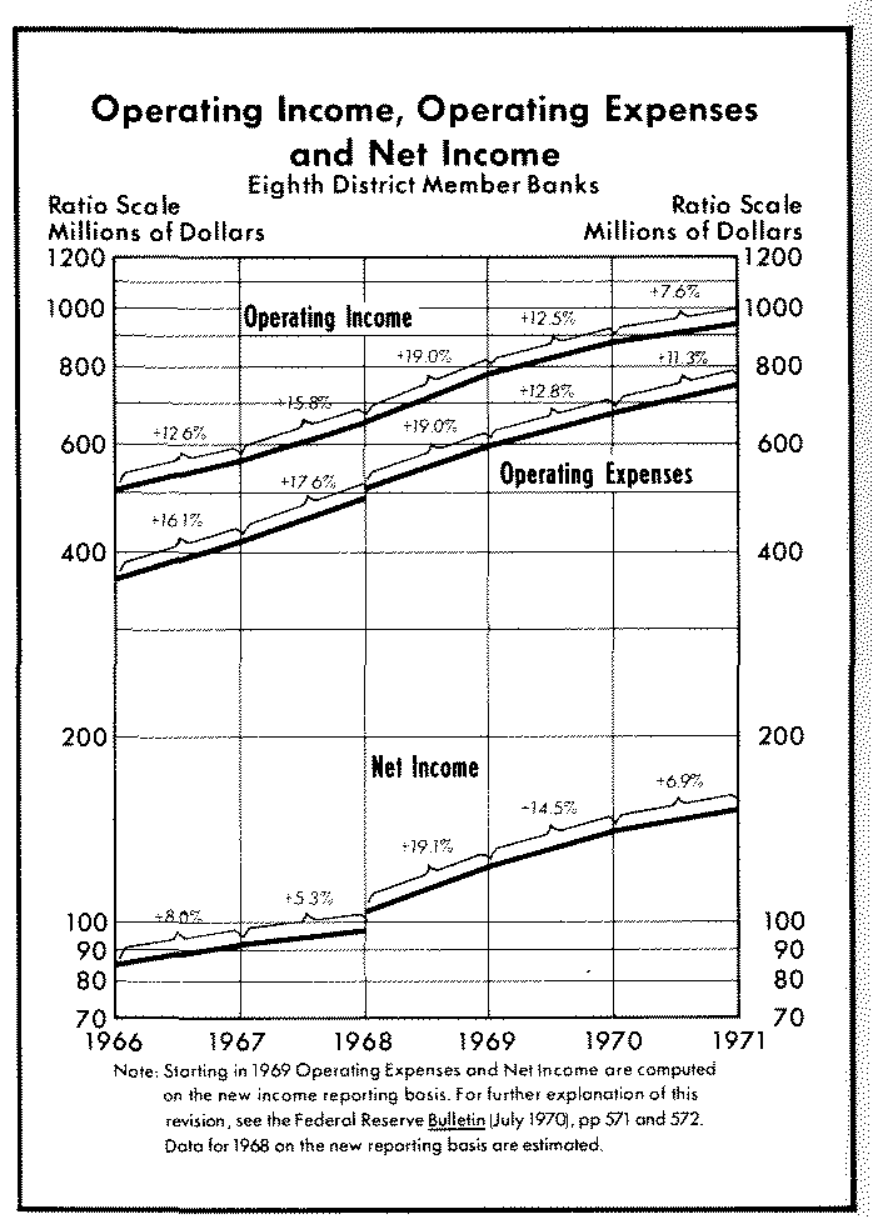

savings throughout the year enabled District banks to increase their total assets 13 percent to $\$ 17.7$ billion, compared to a 10 percent increase in 1970 . Time and savings deposits became a more attractive investment for the public because rates of return on most competing market instruments generally declined relative to rates offered by banks.

Loans outstanding increased 12 percent to $\$ 9.1 \mathrm{bil}$ lion between December 1970 and December 1971 . Loans accounted for 52 percent of total assets at 


\section{INCOME AND EXPENSES OF EIGHTH DISTRICT MEMBER BANKS}

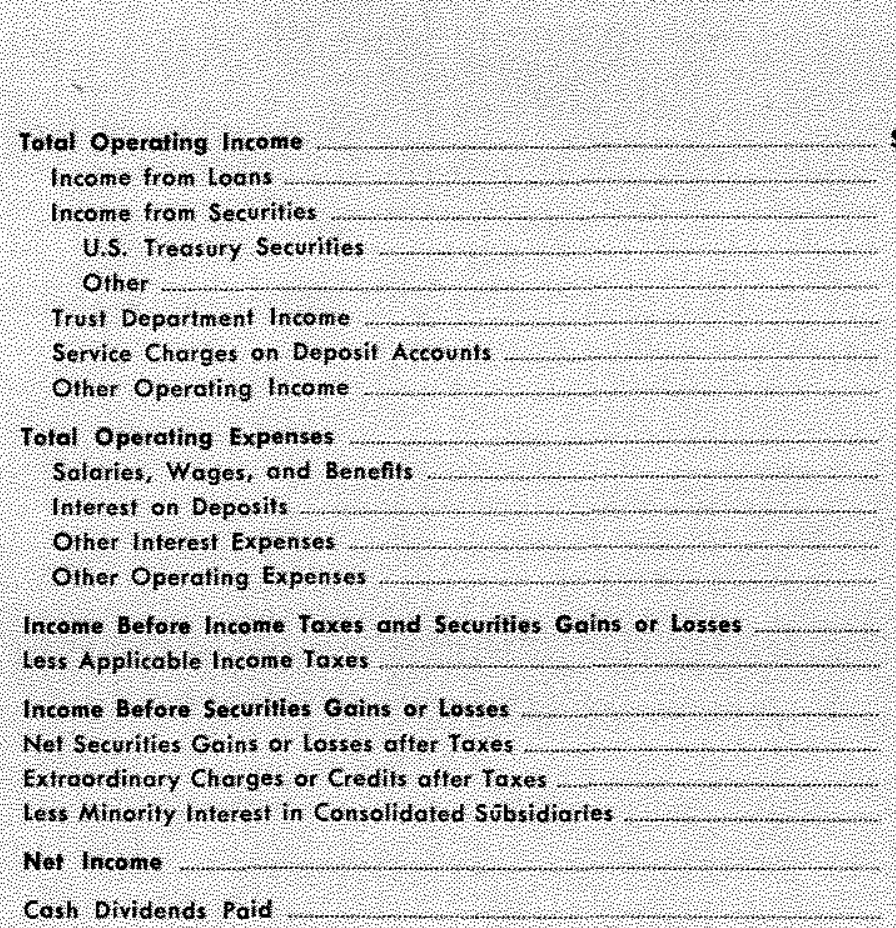

Number of Benks,

\begin{tabular}{|c|c|c|c|c|}
\hline \multicolumn{3}{|c|}{ Thousonot of Dollors } & \multicolumn{2}{|c|}{ Percent Clange } \\
\hline 1971. & 1970 & 1969 & $1970-71$ & 196970 \\
\hline 5944,1942 & $9877,377.3$ & 9779,84411 & $7.6 \%$ & $12.5 \%$ \\
\hline 604.2527 & $391,072,1$ & $526,353,3$ & 22 & 123 \\
\hline 229918.4 & $192,270.6$ & 174,353 & 19.6 & 104 \\
\hline 113,2000 & $103,563.3$ & 938848 & 93 & 103 \\
\hline 116,7184 & 887073 & 00,2500 & 316 & 10.5 \\
\hline $23,732,4$ & $20,710.6$ & $19,500.1$ & 14.6 & 6.2 \\
\hline $27,5,92$ & 20,0119 & $24,50,4$ & $5 \%$ & 31 \\
\hline 587416 & 473121 & 35,0970 & 242 & 348 \\
\hline $747,561,3$ & 671,6825 & 595,71599 & 113 & 128 \\
\hline 200993,1 & 184,4926 & $167,586.2$ & 89 & 101 \\
\hline $373,54 \% 2$ & $261,090.0$ & 225,7172 & 19.8 & 161 \\
\hline 375772 & $30,15.6$ & 50,9001 & -25.0 & 417 \\
\hline $195,136.8$ & $175,081,1$ & 151,492, & 11.5 & 15.6 \\
\hline $106.632 \%$ & $205,69,6$ & 184,1282 & (-) 4.4 & 117 \\
\hline 52,2308 & 65,7674 & 58.538 .6 & -20.6 & 12.4 \\
\hline 14,4011 & 139,9274 & 125,5896 & 32 & 114 \\
\hline $6,028.2$ & 2007 & $-2,378.6$ & $3,11,3$ & 3 \\
\hline 5034 & 1,0247 & 1171 . & 50.9 & 775,1 \\
\hline 250 & $4,14.9$ & 26.6 & 73.2 & $(4,40$ \\
\hline 150,9069 & 141,1979 & $123,301,6$ & 6.9 & 14.5 \\
\hline $62,573,7$ & $48,185,5$ & $43,611,4$ & 29.9 & 10.0 \\
\hline 458 & 459 & 465 & 40,2 & 1.3 \\
\hline
\end{tabular}

all Eighth District member banks, the same as a year earlier. By size of bank, however, the proportion of loans to total assets varied from an average of 53 percent for those banks with $\$ 100$ million or more in deposits to 45 percent for those banks with less than $\$ 5$ million in deposits. In 1971 banks held proportionately more consumer loans, fewer commercial loans, and the same proportion of real estate loans as in 1970. Outstanding consumer loans rose 14 percent, largely reflecting a 16 percent increase in automobile loans. Real estate loans increased 9 percent, and commercial loans rose only 5 percent. Included in the total loan data are Federal funds sold and securities purchased under agreements to resell, which combined increased 47 percent to $\$ 9.6$ million. Eighth District member banks were net lenders in this market in 1971.

Investments at District member banks rose 18 percent to $\$ 5$ billion between December 1970 and December 1971. Holdings of U.S. Treasury securities, which accounted for about 40 percent of total investments, rose 7 percent and other securities, largely tax-exempt state and municipal obligations, rose 26 percent. This large increase in other securities resulted in such holdings rising from 15 to 17 percent of total assets in 1971. U.S. Treasury securities as well as cash

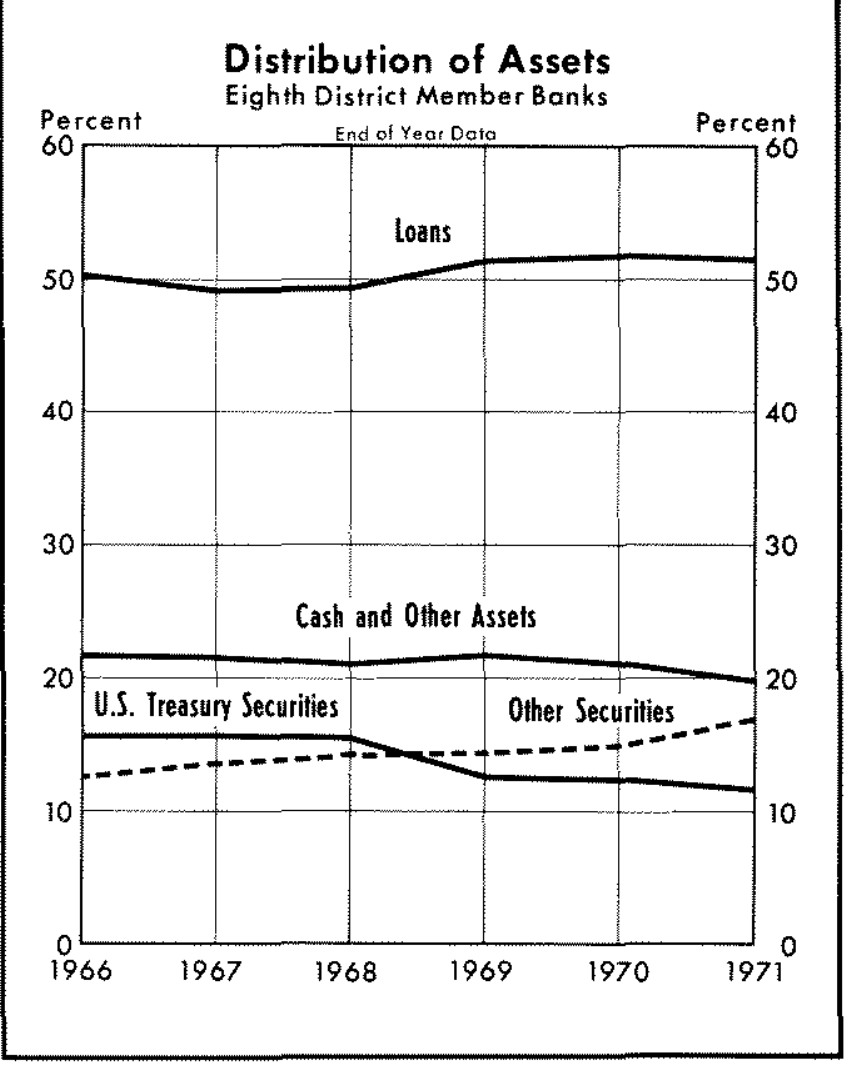


and other nonearning assets declined slightly relative to total assets.

Average rates of return on earning assets remained relatively stable from the previous year with the exception of the rate on loans, which fell about 60 basis points to 7.1 percent. 1 The average rates of return on U.S. Treasury securities and obligations of U.S. Government agencies remained at 5.8 and 6.3 percent, respectively. The rate on obligations of states and political subdivisions combined increased about 20 basis points to 4.1 percent.

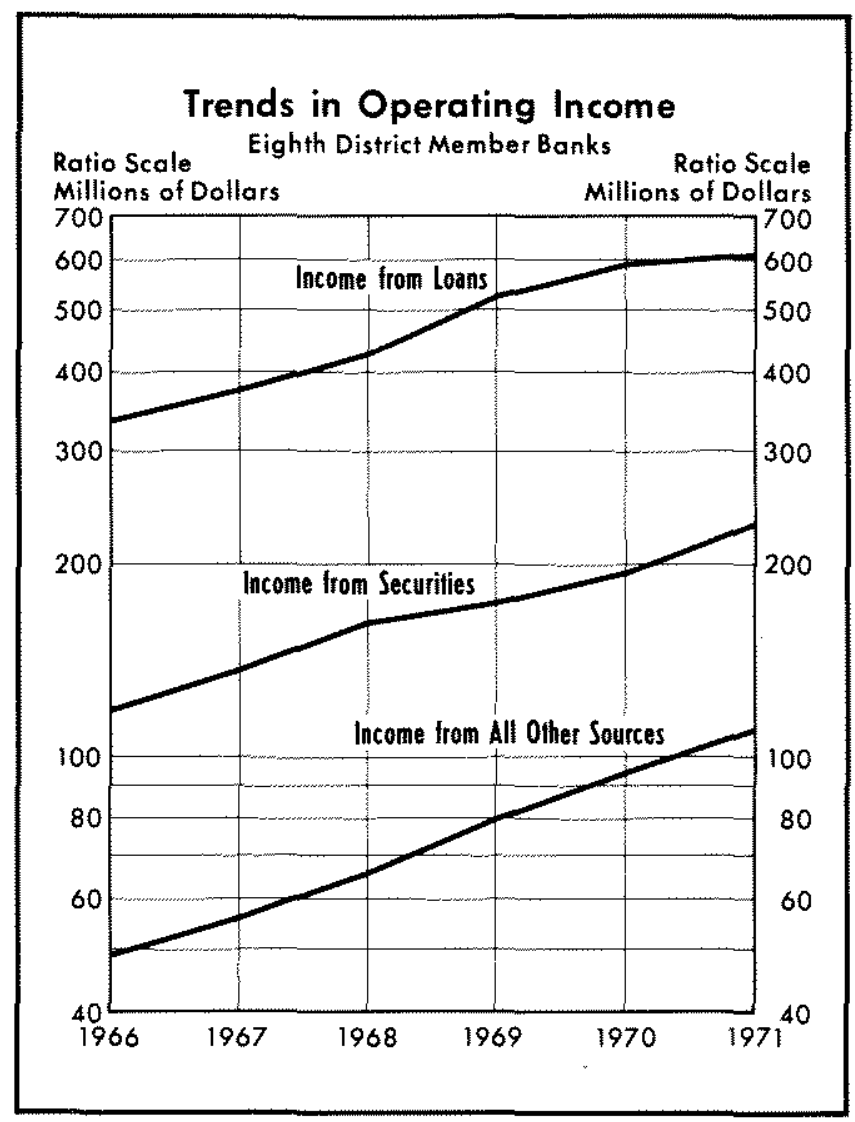

Interest and fees on loans accounted for about twothirds of total operating income but showed little growth in 1971, rising only 2 percent to $\$ 604$ million. Interest on U.S. Treasury securities increased 9 percent to $\$ 113$ million. Returns on all other securities, primarily tax-exempt state and municipal bonds, were the most rapidly rising source of income, increasing 32 percent to $\$ 117$ million. Income from all other sources, including trust department income and service charges on deposit accounts, totaled $\$ 110$ million, an increase of 17 percent from 1970.

\footnotetext{
All rates of return are unweighted averages computed from Reports of Condition for Deoember 31, 1970; June 30, 197 I; and December 31, 1971 and Report of Income for 1971 .
}

Trust income was a more important source of income for the larger than the smaller banks. For example, 4 percent of total operating income was derived from trust operations by those banks holding deposits in excess of $\$ 100$ million. In contrast, only a fraction of a percent of the income of banks with less than $\$ 5$ million in deposits was derived from trust operations.

The growth in income from securities accounted for over one-half of the $\$ 66.8$ million gain in operating income in 1971. Income from tax-exempt state and municipal bonds rose $\$ 16.4$ million, representing al most a quarter of the increase. Due to a decline in average lending rates, returns from loans accounted for only one-fifth of the gain, compared to two-thirds in 1970. Trust department income and service charges on deposit accounts, represented 5 and 2 percent, respectively, of the increase. Miscellaneous income sources, which include safe deposit box rental, property leasing, foreign department operations, and data processing, accounted for 17 percent of the income gain.

\section{Operating Expenses}

Operating expenses of District member banks increased 11 percent in 1971 to $\$ 748$ million. Expenses rose at a faster rate and by a larger absolute amount than operating income, and thus income before income taxes and securities gains or losses fell below the year-earlier level. This growth in expenses can be attributed primarily to a larger volume of time and savings deposits with no change in the average rate paid. Salaries, wages, employee benefits, occupancy and equipment expenses, and provision for loan losses were also higher than in 1970 , but interest paid for borrowed money declined.

Liabilities of member banks increased more rapidly in 1971 than a year earlier. The volume of time and savings deposits increased 20 percent to $\$ 6.9$ billion, a pace even more rapid than in 1970 when regulatory ceiling rates were suspended on large-denomination CDs having maturities of thirty to eighty-nine days. The growth in 1971 resulted from the decline in shortterm market interest rates from 1970 levels relative to the average rate paid on time and savings deposits. Demand deposits at District member banks rose 6 percent to $\$ 8.1$ billion, and other liabilities increased 30 percent to $\$ 1.2$ billion. Federal funds purchased and securities sold under agreements to repurchase, which constituted the major portion of "other liabilities," increased 42 percent. This sharp increase reflects a sizable decline in the interest rate on Federal funds 
relative to the discount rate. In contrast, during most of 1970 the Federal funds rate greatly exceeded the discount rate.

The composition of bank liabilities shifted considerably in 1971 as time and savings deposits continued to grow rapidly. These deposits increased from 37 to 40 percent of total liabilities and capital accounts, while demand deposits fell from 49 to 46 percent. Other liabilities, such as Federal funds purchased and other borrowed funds, increased from 6 to 7 percent, while capital accounts decreased slightly relative to the total.

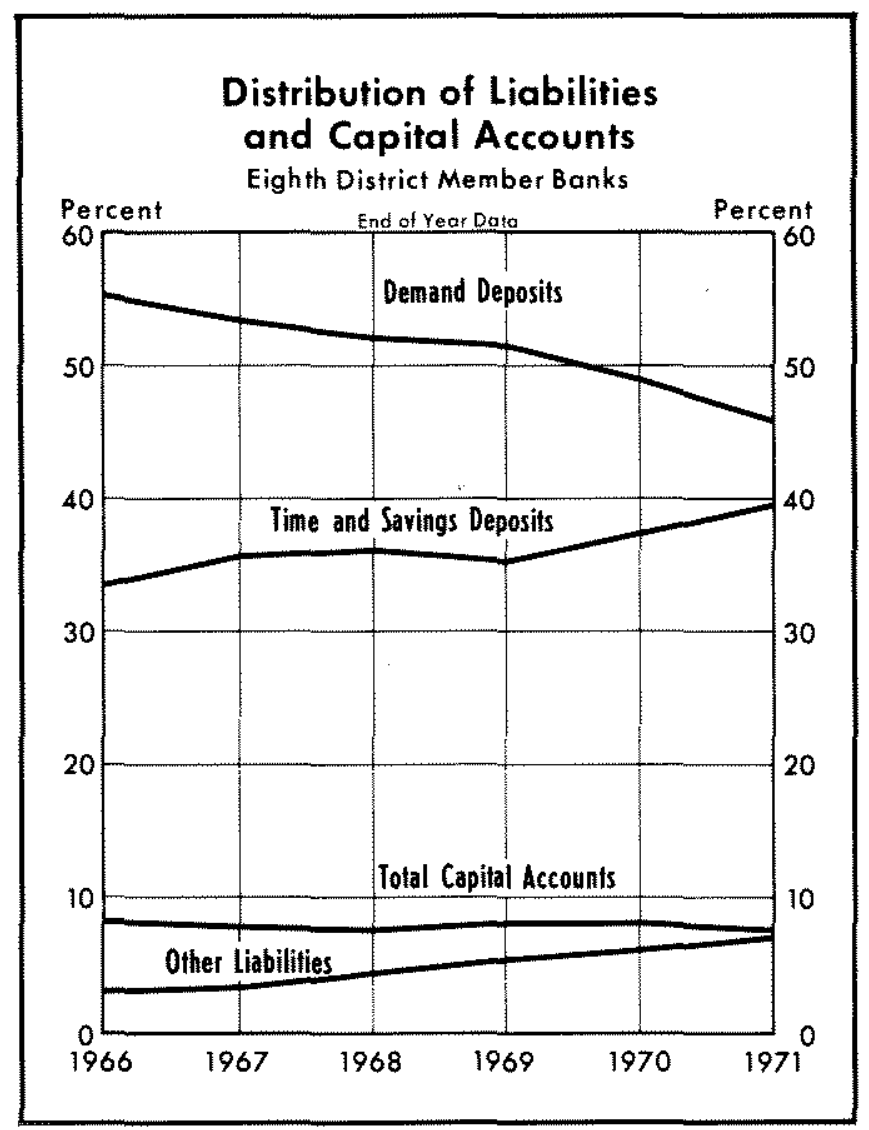

The average rate paid on time and savings deposits remained at 4.9 percent in 1971 . Most banks maintained their rates on regular savings and small-denomination time deposits at or near the regulatory ceilings which have been in effect since early 1970 . However, rates on large-denomination CDs fluctuated with other money market rates.

Interest on time and savings deposits, the most rapidly growing expense item and the only one to exceed the growth rates of 1970 , increased 20 percent to $\$ 314$ million in 1971 . This increase reflected both the rapid growth of time and savings deposits and the relatively stable average rate paid. Other interest ex-

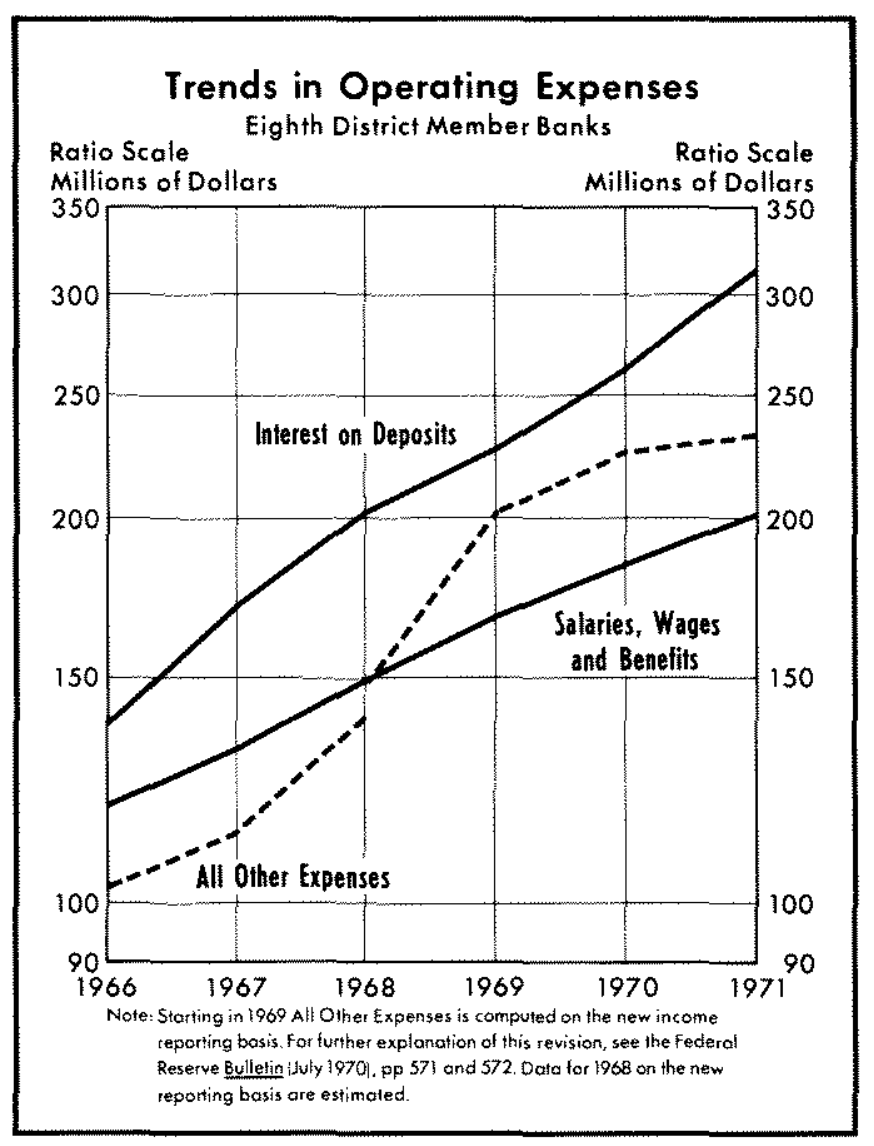

penses declined 25 percent to $\$ 38$ million. This drop resulted from a decline in the average rate paid on Federal funds purchased and securities sold under agreements to repurchase. The average rate on such borrowings declined from 6.6 percent in 1970 to 6.2 percent in 1971. The volume of other borrowed funds, consisting largely of Federal Reserve credit, declined 60 percent, reflecting the differential between the discount rate and market interest rates.

Salaries, wages, and employee benefit expenses rose 9 percent to $\$ 201$ million, reflecting both a rise in average wages paid and an increase of 3 percent in the number of officers and employees. Salaries and wages are a larger percentage of expenses of the very small banks as compared to other banks, reflecting the greater labor intensity of the small banks. Average compensation per person increased only 5 percent in 1971 , reflecting in part the price-wage freeze initiated on August 15, 1971. Remaining expenses rose 12 percent to $\$ 195$ million.

\section{Net Income}

Income before taxes and securities gains or losses of Eighth District member banks in 1971 was $\$ 197$ million, a decrease of 4 percent from 1970. Income 
taxes applicable to operating income declined 21 percent to $\$ 52$ million. This reduction in taxes resulted from increased holdings of tax-exempt securities, removal of the Federal corporate income surtax, a drop in income before taxes and securities gains or losses, and a previous shift in tax accounting techniques from a cash to accrual basis. This considerable decrease in taxes boosted after-tax income 3 percent. Net securities gains after taxes jumped from $\$ 0.3$ million in 1970 to $\$ 6$ million in 1971 , contributing to further improvement in earnings. After adjusting for the net effects of taxes, securities gains or losses, and extraordinary charges, net income increased 7 percent to $\$ 151$ million in 1971.

\section{Bank Capital}

Capital accounts of District member banks - equity capital plus capital notes and debentures - totaled $\$ 1.3$ billion at the end of 1971 , an 8 percent increase from the previous year. Equity capital increased 8 percent to $\$ 1,271$ million, and capital notes and debentures rose 18 percent to $\$ 62$ million. Because of a 30 percent increase in cash dividends to $\$ 63$ million, net retained earnings - the major source of equity capital-declined 5 percent from the previous year to $\$ 88$ million. Net income as a percentage of equity capital declined from 12 percent in 1970 to 11.9 percent in 1971.

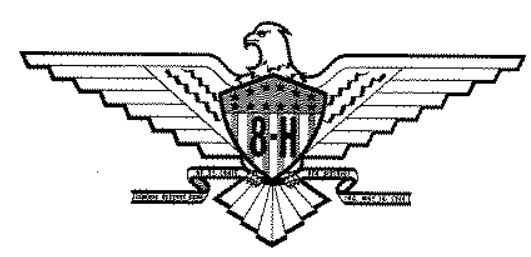

